\title{
Management and outcomes of pituitary apoplexy
}

\author{
Tarun D. Singh, MBBS, ${ }^{1}$ Navid Valizadeh, MB, BCh, BAO, ${ }^{1}$ Fredric B. Meyer, MD, ${ }^{2}$ \\ John L. D. Atkinson, MD, ${ }^{2}$ Dana Erickson, MD, ${ }^{3}$ and Alejandro A. Rabinstein, MD ${ }^{1}$
}

Departments of ${ }^{1}$ Neurology, ${ }^{2}$ Neurosurgery, and ${ }^{3}$ Endocrinology, Mayo Clinic, Rochester, Minnesota

\begin{abstract}
OBJECT This study was undertaken to analyze the predisposing factors, clinical presentation, therapeutic management, and clinical recovery in patients with pituitary apoplexy, with an emphasis on the long-term visual, endocrine, and functional outcomes.

METHODS The authors performed a retrospective analysis of consecutive cases involving patients treated at Mayo Clinic between 1992 and 2013. Patients were included in the study only if they had 1) abrupt onset of severe headache or visual disturbance in the presence of a pituitary adenoma and 2) radiological or surgical confirmation of a pituitary mass. The primary endpoints of analysis were the visual (ocular motility, visual fields, and visual acuity), endocrine, and functional outcomes (using the modified Rankin Scale).
\end{abstract}

RESULTS Eighty-seven patients were identified (57 males and 30 females, mean age 50.9 years, range 15-91 years). Twenty-two patients $(25.3 \%)$ had a known pituitary adenoma. Hypertension was the most common associated factor (39\%). Headache was the most frequent presenting symptom $(89.7 \%)$, followed by visual abnormalities $(47.1 \%)$. Cranial nerve palsies were present in $39 \%$ and visual field defects in $34.1 \%$. MRI detected hemorrhage in $89 \%$ patients, as compared with $42 \%$ detected by CT scan. Sixty-one patients $(70.1 \%)$ underwent surgery during acute hospitalization (median time from apoplexy 5 days, IQR 3-10 days), 8 (9.2\%) had delayed surgery, and $18(20.7 \%)$ were treated conservatively. Histopathological examination revealed adenoma with pure necrosis in $18(30 \%)$, pure hemorrhage in $4(6.7 \%)$, and both in $6(10 \%)$ patients. Four patients died during hospitalization. The average duration of follow-up was $44.2 \pm 43.8$ months. All survivors were independent and had complete resolution or substantial improvement in eye movements and visual fields at the last follow-up. Many patients needed long-term hormonal replacement with levothyroxine (62.7\%) and cortisol $(60 \%)$. Daily desmopressin was needed in $23 \%$ of all surgical patients at 3 months (versus none of the medically treated) and this requirement decreased slightly over time. Regrowth of pituitary adenoma was seen in 7 patients (8.6\%). There were no statistically significant differences in any of the outcome measures across the treatment groups.

CONCLUSIONS The outcome of most patients with pituitary apoplexy is excellent. Selected patients can be managed conservatively, and patients with severe neuro-ophthalmological deficits treated with early surgery can achieve an excellent recovery.

http://thejns.org/doi/abs/10.3171/2014.10.JNS141204

KEY WORDS pituitary apoplexy; pituitary surgery; visual; endocrine; outcomes

$\mathrm{P}$ ITUITARY apoplexy (derived from the Greek word apoplexxia meaning "to cripple by a stroke") refers to a constellation of symptoms characterized by sudden onset of severe headache, visual impairment, vomiting, ophthalmoplegia, and altered consciousness. ${ }^{11,35} \mathrm{It}$ is an uncommon but a well-established clinical entity that occurs due to a rapid expansion of the contents of the sella turcica, mostly caused by hemorrhage or infarction of a preexisting adenoma. ${ }^{11,12}$

The first case of pituitary apoplexy was described by Bailey in $1898 .^{6}$ The term pituitary apoplexy was first used by Brougham et al. in 1950 when describing 5 cases of this clinical entity. ${ }^{11}$ Since then there have been many case series and case reports describing the spectrum of pituitary

ABBREVIATIONS ACTH = adrenocorticotropic hormone; $\mathrm{CN}=$ cranial nerve; $m R S=$ modified Rankin Scale.

SUBMITTED June 4, 2014. ACCEPTED October 8, 2014.

INCLUDE WHEN CITING Published online April 10, 2015; DOI: 10.3171/2014.10.JNS141204.

DISCLOSURE The authors report no conflict of interest concerning the materials or methods used in this study or the findings specified in this paper. 
apoplexy. It occurs in $2 \%-7 \%$ of patients with pituitary adenoma. ${ }^{30}$ With the advent of CT and particularly MRI scans, it is being increasingly detected that subclinical or minimally symptomatic hemorrhage is much more common, occurring in up to $25 \%$ of adenomas; ${ }^{10,26}$ however, the term apoplexy should be reserved for cases with abrupt onset of symptoms. ${ }^{12}$

Resection was traditionally considered the optimal treatment for patients with pituitary apoplexy. ${ }^{8,12,13,31,34}$ However, more recent case series have reported good outcomes with conservative medical therapy., ${ }^{9,21,23,24}$ No randomized studies have been conducted to compare the two management strategies, and guidelines propose individualizing therapy depending on the severity of presentation. ${ }^{30}$

Most of the literature on pituitary apoplexy consists of relatively small case series. Very few series have included more than 50 patients and presented a long-term followup. ${ }^{33}$ In this study, we retrospectively analyzed the clinical presentation, predisposing factors, therapeutic management, and clinical recovery of a large series of pituitary apoplexy patients treated at our institutions over a period of 22 years, with an emphasis on the long-term visual, endocrine, and functional outcomes.

\section{Methods}

The study was approved by our institutional review board. All included patients had signed a general informed consent form allowing their medical records to be used for research purposes. We retrospectively reviewed the records of pituitary apoplexy patients treated from 1992 to 2013. Cases with diagnosis of pituitary apoplexy were identified using our electronic data search system. Patients were included in the study only if they satisfied the following criteria: 1) abrupt onset of severe headache or visual disturbance in the presence of a pituitary adenoma, and 2) radiological or surgical confirmation of a pituitary mass. Patients were included regardless of whether treatment was surgical or conservative. Only the first episode of apoplexy was included in the analysis.

Information on predisposing factors, clinical presentation, diagnostic investigations, management, and followup was obtained from the medical records. Upon admission, all patients were examined by a neurosurgeon, most were also examined by a neurologist, all but 5 were evaluated by an endocrinologist, and 81 were assessed by an ophthalmologist. All patients underwent either CT or MRI scanning of the brain. The results were compared with previous CT and MRI scans in patients with a preexistent diagnosis of a pituitary adenoma. In patients who underwent surgery, a neuropathological examination was performed on the excised tissue, and the tissue was stained immunohistochemically to determine the tumor type.

Patients were categorized into 3 groups on the basis of their treatment: 1) acute surgery, corresponding to those who had surgery during the same hospitalization; 2) delayed surgery, for those who had a planned surgery at a later time after stabilization of their symptoms; and 3) medical management.

The primary endpoints of our analysis were the visual (ocular motility, visual fields, and visual acuity), endo- crine, and functional outcomes. A complete recovery of visual acuity was defined as $20 / 20$ vision or return to the baseline before the onset of apoplexy. Formal campimetry testing was used to measure visual field outcomes. The modified Rankin Scale (mRS) was used to measure the patient's functional status. Visual, endocrine, and functional status measures were collected at the time of discharge, 3-month, 1-year, and at their last follow-up.

Data are presented using the basic descriptive statistics. Fisher's exact test and chi-square tests were used to compare outcomes across the treatment groups.

\section{Results}

We identified 87 patients (57 [65.5\%] males and 30 [34.5\%] females, mean age of 50.9 years [range 15-91 years]) who fulfilled the above criteria for pituitary apoplexy diagnosis during the study period. The average duration of follow-up was $44.2 \pm 43.8$ months (median 36 months, IQR 12-60 months).

\section{Coexistent Factors}

Hypertension (39\%) was the most common comorbidity, followed closely by dyslipidemia (34.5\%) and obesity $(27.5 \%)$. Only a small proportion of the patients had diabetes mellitus (12.6\%). Twelve patients (14.8\%) were active smokers, and $22(27.2 \%)$ were previous smokers. Two patients developed apoplexy after major surgery (cardiothoracic operations in both cases). Only $10.3 \%$ of the patients were receiving anticoagulant therapy with either heparin $(22.2 \%)$ or warfarin $(77.8 \%)$, and $17(19.5 \%)$ were being treated with antiplatelet drugs. Among the women, only 1 was pregnant and 3 were in the postpartum period when they presented with pituitary apoplexy.

\section{Presentation}

The most common presenting symptom was sudden onset of severe headache, which was most commonly described as frontal or retro-orbital. Around half of the patients $(47.1 \%)$ had visual abnormalities in addition to the headache; blurred vision (20\%) was the most common visual complaint. Five patients presented with polyuria and polydipsia suggestive of diabetes insipidus. Thirty-nine percent had cranial nerve $(\mathrm{CN})$ palsies, and unilateral CN III palsy was present in $67.6 \%$ of these cases. Visual field defects were detected in 29 patients (34.1\%), with a predominance of bitemporal hemianopsia (59.3\%). Eight patients $(9.2 \%)$ had an associated weakness, with facial weakness being the most common $(62.5 \%)$.

Prior to the apoplectic event, 22 patients (25.3\%) had a known pituitary adenoma. Twelve had an endocrinologically active tumor (prolactinoma in 9, ACTH-secreting tumor in 2, and gonadotrophic tumor in 1), whereas the tumor was nonfunctional in the other 10.

\section{Diagnostic Investigations}

All patients had radiological confirmation of a sellar mass. Sixty-nine patients (79.3\%) had a CT scan of the head, and a sellar mass was noted in 63 of these 69 cases. A mass was seen in all patients evaluated with MRI of the brain $(\mathrm{n}=82,94 \%)$. Hemorrhage was detected twice as frequently with MRI as with CT scan (Table 1). 
Eighty-two patients (94.3\%) had an endocrinological evaluation done at the time of presentation, and baseline pituitary functions were obtained in these cases. Of these 82 patients, 35 (45.5\%) had abnormally low cortisol levels, and $60 \%$ of the men had low testosterone concentrations. One-third of the patients had low ACTH levels. The detailed hormone profile is summarized in Table 2.

\section{Treatment}

Most of the patients (92\%) were admitted, and 7 patients were treated on an outpatient basis because their acute symptoms subsided rapidly and it was decided to treat them conservatively under close ambulatory supervision. Thirty-eight patients (44.7\%) required admission to the intensive care unit. During the acute hospitalization, 72 patients (83.7\%) were given corticosteroids, 21 (24.4\%) received insulin, $31(35.6 \%)$ received levothyroxine, 7 (8\%) received desmopressin, and $4(4.6 \%)$ received bromocriptine. The median length of hospital stay was 5 days (IQR 3-9 days, mean 7.2 \pm 6.1 days).

Sixty-one patients $(70.1 \%)$ underwent surgery with a median time of 5 days (IQR 3-10 days) from symptom onset, whereas 8 patients $(9.2 \%)$ underwent scheduled surgery after a median of 126 days (IQR 64-776 days) following the acute presentation and medical stabilization. All patients treated with surgery underwent transsphenoidal resection. Eighteen cases (20.7\%) were managed conservatively with medical treatment. Of the 79 patients with evidence of hemorrhage on MRI, 59 (80.8\%) underwent surgery, and of the 7 with MRI evidence of infarct, $6(85.7 \%)$ underwent surgery (Table 3). Visual deficits (decreased field or acuity) and oculomotor abnormalities were more common in the surgery group than in the conservative management group (47 [68.1\%] 69 vs 8 [44.4\%] 18 ), although the difference did not reach statistical significance $(\mathrm{p}=0.06)$.

Histopathological examination of the resected tissue revealed an adenoma in 64 cases and Rathke cleft cyst in 4 cases. Frank necrotic tissue was present in 10 cases $(16.7 \%)$, while pituitary adenoma with pure necrosis was present in $18(30 \%)$, pure hemorrhage in $4(6.7 \%)$, and a mixture of both in $6(10 \%)$. Null cell adenoma was identified in 18 cases and prolactinoma in 8; other types of adenoma were even less common.

\section{Outcomes}

The endocrinological outcomes categorized by therapeutic strategy are presented in Table 2 , functional and radiological outcomes in Table 4, and ophthalmological outcomes in Table 5. Improvement was noted during the acute hospitalization but continued over time. There were no statistically significant differences in any of the outcome measures across the treatment groups. The patients who had reduced consciousness at presentation (14.9\%) recovered favorably. Four patients $(4.6 \%)$ died during the acute hospitalization ( 2 who were treated conservatively and 2 who underwent early surgery): 1) an 89-year-old patient who had a massive frontal hemorrhage along with pituitary apoplexy; 2) a 67-year-old patient with multiple comorbidities precluding safe surgery; 3) a 77-year-old patient with an amyloid cardiomyopathy who developed
TABLE 1. Radiological findings

\begin{tabular}{lc}
\hline \multicolumn{1}{c}{ Modality \& Finding } & Value $^{*}$ \\
\hline $\mathrm{CT}$ & $69(79.3)$ \\
\hline Mass & $63(91.3)$ \\
\hline Median size of mass in mm (IQR) & $22(20-28)$ \\
\hline Hemorrhage & $29(42)$ \\
\hline MRI & $82(94.3)$ \\
\hline Mass & $82(100)$ \\
\hline Size of mass (mm) & 25.5 \\
\hline Median & $20-30$ \\
\hline IQR & $73(89)$ \\
\hline Hemorrhage & $21(25.6)$ \\
\hline Mass increase & $7(8.5)$ \\
\hline Infarct & $51(62.2)$ \\
\hline Optic chiasm involvement & $34(41.5)$ \\
\hline Cavernous sinus involvement
\end{tabular}

* Values represent numbers of patients (\%) unless otherwise indicated.

massive hypotension after surgery and was then transitioned to palliative care according to family wishes; and 4) an 89-year-old patient who developed airway complications after surgery and was transitioned to palliative care by family request. Postoperative complications were present in 3 patients who had transient postoperative CSF leaks (without any cases of meningitis), while 3 had severe headache controlled with narcotics, and 1 had postoperative urinary retention.

At last follow-up, all survivors were independent and had minimal or no symptoms. Limitations in eye movements improved in all cases and most often resolved early. A very small minority of patients had no improvement (3 cases) of peripheral vision, all in the early surgical group. Long-term hormonal replacement with levothyroxine was needed in nearly half of the patients, glucocorticosteroids in two-thirds of the patients, and testosterone in close to half of the men. The rates of requiring replacement of anterior pituitary hormones were not significantly different between surgical and medical treatment groups. Daily desmopressin was needed in $23 \%$ of all surgical patients at 3 months (vs none of the medically treated patients), and this requirement decreased slightly over time. Regrowth of the pituitary adenoma was seen in 7 (8.6\%) patients, all after surgery; repeat surgery was done in 1, radiotherapy in 4 patients, and the other 2 were only monitored as they remained asymptomatic. There were no cases of pituitary apoplexy recurrence.

\section{Discussion}

Our study of a large series of patients with pituitary apoplexy, one of the largest collected to date, highlights that this severe condition typically has excellent outcomes with adequate therapy. Early surgery remains the mainstay of treatment, but selected patients can recover very well with a delayed, planned resection or solely with medical therapy. Neurological and ophthalmological symptoms improve early after treatment and fully resolve in most cases over time. Long-term replacement of anterior pitu- 
TABLE 2. Endocrinological status at presentation and follow-up categorized by treatment strategy*

\begin{tabular}{|c|c|c|c|}
\hline Time Point \& Variable & $\begin{array}{l}\text { Conservative Management } \\
\qquad(n=18)\end{array}$ & Early Surgery $(n=61)$ & Delayed Surgery $(n=8)$ \\
\hline \multicolumn{4}{|l|}{ Abnormal findings at presentation } \\
\hline Low thyroid-stimulating hormone & $15(88.2 \%)$ & $16(30.2 \%)$ & $1(12.5 \%)$ \\
\hline Low testosterone & $4(44.4 \%)$ & $20(64.5 \%)$ & $3(60 \%)$ \\
\hline Low cortisol & $8(47.1 \%)$ & $23(44.2 \%)$ & $4(50 \%)$ \\
\hline Low ACTH & $3(27.3 \%)$ & $12(41.4 \%)$ & 0 \\
\hline Low prolactin & $3(17.6 \%)$ & $19(35.2 \%)$ & $2(28.6 \%)$ \\
\hline High prolactin & $5(29.4 \%)$ & $6(11.1 \%)$ & $2(28.6 \%)$ \\
\hline Low luteinizing hormone & $5(38.5 \%)$ & $18(40.9 \%)$ & $1(14.3 \%)$ \\
\hline Low follicle-stimulating hormone & $3(27.3 \%)$ & $6(15.8 \%)$ & 0 \\
\hline Low growth hormone & $1(20 \%)$ & $4(26.7 \%)$ & 0 \\
\hline Low insulin-like growth factor-1 & $6(50 \%)$ & $13(37.1 \%)$ & $1(25 \%)$ \\
\hline Replacement therapy at 3-mo follow-up & $14(87.5 \%)$ & $57(96.6 \%)$ & $7(87.5 \%)$ \\
\hline Levothyroxine & $5(35.7 \%)$ & $27(47.4 \%)$ & $3(42.9 \%)$ \\
\hline Cortisone & $7(50 \%)$ & $42(73.7 \%)$ & $3(42.9 \%)$ \\
\hline Testosterone & $1(12.5 \%)$ & $21(50 \%)$ & $2(40 \%)$ \\
\hline Estradiol & $4(40 \%)$ & $3(20 \%)$ & 0 \\
\hline Progesterone & $2(20 \%)$ & $2(13.3 \%)$ & 0 \\
\hline Growth hormone & 0 & 0 & 0 \\
\hline Dopamine antagonist & $1(7.1 \%)$ & $4(7 \%)$ & 0 \\
\hline Desmopressin & 0 & $10(17.5 \%)$ & $2(28.6 \%)$ \\
\hline Replacement therapy at 1-yr follow-up & $11(68.7 \%)$ & $37(62.7 \%)$ & $5(62.5 \%)$ \\
\hline Levothyroxine & $5(41.7 \%)$ & $22(59.5 \%)$ & $3(60 \%)$ \\
\hline Cortisone & $4(33.3 \%)$ & $26(70.3 \%)$ & $3(60 \%)$ \\
\hline Testosterone & $1(33.3 \%)$ & $20(66.7 \%)$ & $2(66.7 \%)$ \\
\hline Estradiol & $4(50 \%)$ & $2(28.6 \%)$ & 0 \\
\hline Progesterone & $2(25 \%)$ & $2(28.6 \%)$ & 0 \\
\hline Growth hormone & 0 & $1(2.7 \%)$ & $1(20 \%)$ \\
\hline Dopamine antagonist & $1(8.3 \%)$ & $3(8.2 \%)$ & $1(20 \%)$ \\
\hline Desmopressin & 0 & $5(13.5 \%)$ & $2(40 \%)$ \\
\hline Replacement therapy at last follow-up & $9(56.3 \%)$ & $25(42.4 \%)$ & $6(75 \%)$ \\
\hline Levothyroxine & $4(44.4 \%)$ & $24(66.7 \%)$ & $4(66.7 \%)$ \\
\hline Cortisone & $4(44.4 \%)$ & $22(62.9 \%)$ & $4(66.7 \%)$ \\
\hline Testosterone & $2(100 \%)$ & $18(64.3 \%)$ & $3(75 \%)$ \\
\hline Estradiol & $5(71.4 \%)$ & $2(25 \%)$ & $1(50 \%)$ \\
\hline Progesterone & $2(28.6 \%)$ & $2(25 \%)$ & $1(50 \%)$ \\
\hline Growth hormone & 0 & $1(2.9 \%)$ & $1(16.7 \%)$ \\
\hline Dopamine antagonist & $1(11.1 \%)$ & $4(11.4 \%)$ & $2(33.3 \%)$ \\
\hline Desmopressin & 0 & $3(8.6 \%)$ & $1(16.7 \%)$ \\
\hline
\end{tabular}

itary hormones (particularly glucocorticosteroids) is necessary in more than half of patients, but only a minority require desmopressin after the acute phase.

Multiple precipitating or predisposing factors have been noted in the literature, ${ }^{9}$ including hypertension, ${ }^{32}$ major surgery, ${ }^{1,2}$ hypotension,,${ }^{15}$ closed head trauma,${ }^{18}$ head radiation, ${ }^{36}$ anticoagulation or intrinsic coagulopathy, ${ }^{27,37}$ pregnancy/postpartum state, ${ }^{7,14,32}$ dynamic pituitary test- ing, $4,21,22$ and bromocriptine initiation or withdrawal. ${ }^{19}$ However, none of these factors is likely to be solely responsible for the occurrence of apoplexy. In our cohort, hypertension was the most common coexistent condition (39\%), followed by treatment with anticoagulant or antiplatelet medication (29.8\%). Major surgery and pregnancy/ postpartum state were uncommon occurrences. None of the other factors previously reported as predisposing to pi- 
TABLE 3. Patient characteristics at baseline categorized by treatment strategy

\begin{tabular}{lcccc}
\hline Characteristic & $\begin{array}{c}\text { Conservative } \\
\text { Management } \\
(\mathrm{n}=18)\end{array}$ & $\begin{array}{c}\text { Early } \\
\text { Surgery } \\
(\mathrm{n}=61)\end{array}$ & $\begin{array}{c}\text { Delayed } \\
\text { Surgery } \\
(\mathrm{n}=8)\end{array}$ & $\begin{array}{c}\mathrm{p} \\
\text { Value }\end{array}$ \\
\hline Age (yrs) & & & & 0.4364 \\
\hline Median & 55.5 & 54 & 44.5 & \\
\hline IQR & $38-82$ & $42-67.5$ & $33-62$ & \\
\hline $\begin{array}{c}\text { History of hyperten- } \\
\text { sion }\end{array}$ & $7(38.9 \%)$ & $25(41 \%)$ & $2(25 \%)$ & 0.6701 \\
\hline $\begin{array}{l}\text { Known adenoma } \\
\text { No visual complaints }\end{array}$ & $4(22.2 \%)$ & $14(23 \%)$ & $4(50 \%)$ & 0.2847 \\
\hline $\begin{array}{c}\text { Reduced conscious- } \\
\text { ness }\end{array}$ & $6(33.3 \%)$ & $28(46 \%)$ & $5(62.5 \%)$ & 0.0904 \\
\hline $\begin{array}{c}\text { Compression of optic } \\
\text { chiasm on MRI }\end{array}$ & $4(33.3 \%)$ & $43(79.6 \%)$ & $4(50 \%)$ & 0.0046 \\
\hline
\end{tabular}

tuitary apoplexy were present in our patients. Around 75\% of our patients had an undiagnosed pituitary adenoma at the time of presentation, which is consistent with previous reports..$^{30}$ Infarction in the pituitary adenomas was present in 33 cases $(55 \%)$, while $10(16.7 \%)$ showed only necrotic tissue, which is also similar to previous series. ${ }^{24}$

The most common and earliest symptom of pituitary apoplexy is a sudden, severe, retro-orbital or frontal headache, often accompanied by visual abnormalities. ${ }^{34}$ The cause of visual problems is the lateral compression of the contents of the cavernous sinus or the optic chiasm. In our study, headache was present in nearly $90 \%$ of patients and was associated with nausea/vomiting in nearly $40 \%$. Visual alteration was reported by almost half of our patients, with ophthalmoparesis present in 39\% and visual field restriction in one-third. These rates of ophthalmological abnormalities are quite similar to those reported in contemporary series but lower than in older series, ${ }^{28,34}$ likely because of more delayed diagnosis before the advent of MRI.

There has been a radical change in the radiological investigations used to diagnose apoplexy in the last 2 decades. Initially, CT scanning was used to diagnose the presence of hemorrhage in the adenoma. ${ }^{36}$ In our cohort of patients, CT was very effective in identifying the presence of pituitary mass, but it could only identify hemorrhage in $42 \%$ of patients. Instead, MRI was extremely sensitive for the detection of hemorrhage into the pituitary mass; the rate of MRI-detected hemorrhage in our study (89\%) is comparable to that reported for other smaller modern series. ${ }^{20,29,31,33}$ MRI can also be used to assess the tissue surrounding the pituitary mass and hence may alter the eventual management of the patients. In our study, optic chiasm compression was seen in $62.2 \%$ and extension of the tumor into the cavernous sinus was seen in $41.5 \%$ patients. Nearly $80 \%$ of the patients who were treated surgically had visible compression of the optic chiasm. Hence, it is now clear that MRI should be the diagnostic imaging of choice in patients with suspected pituitary apoplexy.

The acute management of pituitary apoplexy consists of stabilizing the physiological state of the patient with
TABLE 4. Functional and radiological outcomes categorized by treatment strategy

\begin{tabular}{|c|c|c|c|}
\hline Variable & $\begin{array}{l}\text { Conservative } \\
\text { Management } \\
\quad(n=18)\end{array}$ & $\begin{array}{c}\text { Early } \\
\text { Surgery } \\
(n=61)\end{array}$ & $\begin{array}{c}\text { Delayed } \\
\text { Surgery } \\
(n=8)\end{array}$ \\
\hline \multicolumn{4}{|l|}{ Functional outcome } \\
\hline Death before 3 months & $2(11.1 \%)$ & $2(3.3 \%)$ & 0 \\
\hline \multicolumn{4}{|l|}{ mRS at 3 months } \\
\hline 0 & $9(56 \%)$ & $33(55.9 \%)$ & $3(42.9 \%)$ \\
\hline 1 & $5(31.3 \%)$ & $24(40.6 \%)$ & $4(57.1 \%)$ \\
\hline 2 & 0 & $1(1.6 \%)$ & 0 \\
\hline 6 & $2(12.7 \%)$ & $1(1.6 \%)$ & 0 \\
\hline \multicolumn{4}{|l|}{$\mathrm{mRS}$ at 1 year } \\
\hline 0 & $7(53.8 \%)$ & $28(75.7 \%)$ & $5(100 \%)$ \\
\hline 1 & $5(38.5 \%)$ & $8(21.6 \%)$ & 0 \\
\hline 2 & $1(7.7 \%)$ & 0 & 0 \\
\hline 4 & 0 & $1(2.7 \%)$ & 0 \\
\hline \multicolumn{4}{|l|}{$\begin{array}{l}\text { mRS score at last follow- } \\
\text { up* }\end{array}$} \\
\hline 0 & $5(55.6 \%)$ & $22(66.7 \%)$ & $6(100 \%)$ \\
\hline 1 & $3(33.3 \%)$ & $8(24.2 \%)$ & 0 \\
\hline 6 & $1(11.1 \%)$ & $3(9 \%)$ & 0 \\
\hline \multicolumn{4}{|l|}{ Radiological† } \\
\hline \multicolumn{4}{|l|}{ Follow-up at 3 months } \\
\hline Stable size & $6(46.2 \%)$ & $44(80 \%)$ & $6(75 \%)$ \\
\hline Reduced size & $7(53.8 \%)$ & $11(20 \%)$ & $2(25 \%)$ \\
\hline Increased size & 0 & 0 & 0 \\
\hline \multicolumn{4}{|l|}{ Follow-up at 1 year } \\
\hline Stable size & $8(61.5 \%)$ & $36(90 \%)$ & $5(100 \%)$ \\
\hline Reduced size & $5(38.5 \%)$ & $1(2.5 \%)$ & 0 \\
\hline Increased size & 0 & $3(7.5 \%)$ & 0 \\
\hline \multicolumn{4}{|l|}{ Last follow-up } \\
\hline Stable size & $12(92.3 \%)$ & $27(87.1 \%)$ & $3(75 \%)$ \\
\hline Reduced size & $1(7.7 \%)$ & $1(3.2 \%)$ & 0 \\
\hline Increased size & 0 & $3(9.7 \%)$ & $1(25 \%)$ \\
\hline \multicolumn{4}{|c|}{$\begin{array}{l}\text { * Median amount of time from initial presentation to last follow-up: } 24 \text { months } \\
\text { (IQR 24-54 months) for the conservative management group, } 36 \text { months } \\
\text { (IQR 24-60 months) for the early surgery group, and } 48 \text { months (IQR 21.3-75 } \\
\text { months) for the delayed surgery group. } \\
\text { † The imaging findings were compared to the postoperative CT/MRI in the } \\
\text { surgical patients and to the last in-hospital CT/MRI in the nonsurgical patients. } \\
\text { F Median amount of time from initial presentation to last follow-up: } 24 \text { months } \\
\text { (IQR 24-48 months) for the conservative management group, } 48 \text { months } \\
\text { (IQR 36-72 months) for the early surgery group, and } 42 \text { months (IQR 15.8-78 } \\
\text { months) for the delayed surgery group. }\end{array}$} \\
\hline
\end{tabular}

the supplementation of corticosteroids and other deficient hormones and maintaining electrolyte balance. Traditionally, most patients with apoplexy were treated surgically after this initial stabilization. ${ }^{3,8,13,16,31}$ However, more recent series have repeatedly reported good outcomes in selected patients treated conservatively with medical therapy only. ${ }^{5,9,13,17,21,23,25,31}$ In our study, $70 \%$ of the patients were treated with early resection, but the rest were treated with a delayed, planned surgical intervention (9\%) or solely with medical treatment (21\%). Treatment outcomes 
TABLE 5. Ophthalmological status at presentation and follow-up categorized by treatment strategy

\begin{tabular}{|c|c|c|c|}
\hline Time Point \& Variable & $\begin{array}{c}\text { Conservative } \\
\text { Management } \\
\quad(n=18)\end{array}$ & $\begin{array}{c}\text { Early } \\
\text { Surgery } \\
(n=61)\end{array}$ & $\begin{array}{c}\text { Delayed } \\
\text { Surgery } \\
(n=8)\end{array}$ \\
\hline \multicolumn{4}{|l|}{ At presentation } \\
\hline Visual field defects & $3(16.7 \%)$ & $23(39 \%)$ & $3(37.5 \%)$ \\
\hline $\begin{array}{l}\text { Unilateral right upper quad- } \\
\text { rant }\end{array}$ & $2(11.1 \%)$ & 0 & $1(12.5 \%)$ \\
\hline $\begin{array}{l}\text { Unilateral right lower quad- } \\
\text { rant }\end{array}$ & 0 & $1(1.7 \%)$ & $1(12.5 \%)$ \\
\hline $\begin{array}{l}\text { Unilateral left upper quad- } \\
\text { rant }\end{array}$ & $1(5.6 \%)$ & 0 & 0 \\
\hline $\begin{array}{l}\text { Unilateral left lower quad- } \\
\text { rant }\end{array}$ & 0 & 0 & 0 \\
\hline Bitemporal hemianopia & 0 & $16(27.1 \%)$ & $1(12.5 \%)$ \\
\hline Unilateral hemianopia & 0 & $2(3.4 \%)$ & 0 \\
\hline Bilateral inferior & 0 & $2(3.4 \%)$ & 0 \\
\hline $\begin{array}{l}\text { Unilateral total \& contralat- } \\
\text { eral temporal }\end{array}$ & 0 & $2(3.4 \%)$ & 0 \\
\hline Decreased visual acuity & $5(31.3 \%)$ & $28(45.9 \%)$ & $5(62.5 \%)$ \\
\hline Eye movement disorder & $6(33.3 \%)$ & $40(65.6 \%)$ & $1(12.5 \%)$ \\
\hline Unilateral CN III & $2(11.1 \%)$ & $21(34.4 \%)$ & 0 \\
\hline Unilateral CN IV & 0 & $4(6.6 \%)$ & 0 \\
\hline Unilateral CN VI & $1(5.6 \%)$ & $8(13.1 \%)$ & $1(12.5 \%)$ \\
\hline Bilateral CN III & $1(5.6 \%)$ & $2(3.3 \%)$ & 0 \\
\hline Bilateral CN IV & $1(5.6 \%)$ & 0 & 0 \\
\hline Bilateral CN VI & $1(5.6 \%)$ & 0 & 0 \\
\hline Unilateral ophthalmoplegia & 0 & $4(6.6 \%)$ & 0 \\
\hline Bilateral ophthalmoplegia & 0 & $1(1.6 \%)$ & 0 \\
\hline Follow-up at 3 months & $14(87.5 \%)$ & $54(90 \%)$ & $8(100 \%)$ \\
\hline \multicolumn{4}{|l|}{ Visual fields } \\
\hline Normal & $13(92.8 \%)$ & $45(83.3 \%)$ & $6(75 \%)$ \\
\hline Total improvement* & $2(66.7 \%)$ & $12(57.1 \%)$ & $1(33.3 \%)$ \\
\hline Partial improvement* & $1(33.3 \%)$ & $7(33.3 \%)$ & $2(66.7 \%)$ \\
\hline No improvement* & 0 & $2(9.6 \%)$ & 0 \\
\hline Worsened* $^{*}$ & 0 & 0 & 0 \\
\hline \multicolumn{4}{|l|}{ Visual acuity } \\
\hline Normal & $13(92.8 \%)$ & $49(90.7 \%)$ & $7(87.5 \%)$ \\
\hline Total improvement* & $4(80 \%)$ & $21(80.8 \%)$ & $4(80 \%)$ \\
\hline Partial improvement* & $1(20 \%)$ & $4(15.4 \%)$ & $1(20 \%)$ \\
\hline No improvement* & 0 & $1(3.8 \%)$ & 0 \\
\hline \multicolumn{4}{|l|}{ Eye movements } \\
\hline Normal & $14(100 \%)$ & $50(92.6 \%)$ & $7(87.5 \%)$ \\
\hline Total improvement* & $4(100 \%)$ & $23(85.2 \%)$ & 0 \\
\hline Partial improvement* & 0 & $4(14.8 \%)$ & $1(100 \%)$ \\
\hline No improvement* & 0 & 0 & 0 \\
\hline Follow-up at 1 year & $13(81.3 \%)$ & $35(61.4 \%)$ & $5(62.5 \%)$ \\
\hline \multicolumn{4}{|l|}{ Visual fields } \\
\hline Normal & $12(92.3 \%)$ & $30(85.7 \%)$ & $4(80 \%)$ \\
\hline Total improvement* & $1(50 \%)$ & $31(86.1 \%)$ & $1(50 \%)$ \\
\hline
\end{tabular}

TABLE 5. Ophthalmological status at presentation and follow-up categorized by treatment strategy (continued)

\begin{tabular}{|c|c|c|c|}
\hline Time Point \& Variable & $\begin{array}{l}\text { Conservative } \\
\text { Management } \\
\quad(n=18)\end{array}$ & $\begin{array}{c}\text { Early } \\
\text { Surgery } \\
(n=61)\end{array}$ & $\begin{array}{c}\text { Delayed } \\
\text { Surgery } \\
(n=8)\end{array}$ \\
\hline \multicolumn{4}{|c|}{ Follow-up at 1 year (continued) } \\
\hline \multicolumn{4}{|l|}{ Visual fields (continued) } \\
\hline Partial improvement* & $1(50 \%)$ & $3(8.3 \%)$ & $1(50 \%)$ \\
\hline No improvement* & 0 & $2(5.6 \%)$ & 0 \\
\hline \multicolumn{4}{|l|}{ Visual acuity } \\
\hline Normal & $12(92.3 \%)$ & $34(97.1 \%)$ & $5(100 \%)$ \\
\hline Total improvement* & $3(75 \%)$ & $14(93.3 \%)$ & $4(100 \%)$ \\
\hline Partial improvement ${ }^{*}$ & $1(25 \%)$ & 0 & 0 \\
\hline No improvement ${ }^{*}$ & 0 & $1(6.7 \%)$ & 0 \\
\hline \multicolumn{4}{|l|}{ Eye movements } \\
\hline Normal & $13(100 \%)$ & $34(97.1 \%)$ & $5(100 \%)$ \\
\hline Total improvement* & $4(100 \%)$ & $16(94.1 \%)$ & $1(100 \%)$ \\
\hline Partial improvement* & 0 & $1(5.9 \%)$ & 0 \\
\hline No improvement* & 0 & 0 & 0 \\
\hline \multicolumn{4}{|l|}{ Maximum follow-up $\dagger$} \\
\hline \multicolumn{4}{|l|}{ Visual fields } \\
\hline Normal & $9(90 \%)$ & $29(90.6 \%)$ & $4(80 \%)$ \\
\hline Total improvement* & 0 & $29(90.6 \%)$ & $2(66.7 \%)$ \\
\hline Partial improvement* & $1(100 \%)$ & $2(6.3 \%)$ & $1(33.3 \%)$ \\
\hline No improvement* & 0 & $1(3.1 \%)$ & 0 \\
\hline \multicolumn{4}{|l|}{ Visual acuity } \\
\hline Normal & $8(80 \%)$ & $30(93.8 \%)$ & $5(100 \%)$ \\
\hline Total improvement* & $3(75 \%)$ & $10(90.9 \%)$ & $5(100 \%)$ \\
\hline Partial improvement* & $1(25 \%)$ & 0 & 0 \\
\hline No improvement* & 0 & $1(9.1 \%)$ & 0 \\
\hline \multicolumn{4}{|l|}{ Eye movements } \\
\hline Normal & $10(100 \%)$ & $32(100 \%)$ & $5(100 \%)$ \\
\hline Total improvement & $3(100 \%)$ & $14(100 \%)$ & $1(100 \%)$ \\
\hline Partial improvement* & 0 & 0 & 0 \\
\hline No improvement* & 0 & 0 & 0 \\
\hline
\end{tabular}

* In patients with abnormalities at presentation.

$†$ Median amount of time from initial presentation to last follow-up: 24 months (IQR 22.5-45 months) for the conservative management group, 36 months (IQR 24-60 months) for the early surgery group, and 36 months (IQR $21.25-66$ months) for the delayed surgery group.

were similarly favorable with all treatment approaches. However, it is important to bear in mind that treatment selection was decided by the neurosurgeon in collaboration with members of the multidisciplinary clinical team and patients treated with early surgery were more likely to have neuro-ophthalmological deficits at presentation. This selection bias, whereby more severe cases are treated surgically while milder presentations are managed conservatively, has been previously noted by others. ${ }^{5,23}$ Nonetheless, it is worth noticing that one-third of the patients treated conservatively in our series had presented with reduced level of consciousness and despite this severe presentation most of them (4 of 6) had an excellent recovery. Therefore, conservative management is a valid strategy for patients 
TABLE 6. Comparison of Mayo Clinic experience with the treatment of pituitary apoplexy for the periods 1975-1991 and 1992-2013

\begin{tabular}{|c|c|c|}
\hline Variable & Bills et al. & Present Study \\
\hline Time period & $1975-1991$ & 1992-2013 \\
\hline No. of patients & 37 & 87 \\
\hline Male/female & $25 / 12$ & $57 / 30$ \\
\hline Mean age (years) & 56.6 & 53.6 \\
\hline Average follow-up (years) & 2.8 & 4.1 \\
\hline \multicolumn{3}{|l|}{ Presenting symptoms/signs } \\
\hline Headaches (\%) & 95 & 89.7 \\
\hline Ocular paresis (\%) & 78 & 39 \\
\hline CN III & 57 & 76.4 \\
\hline CN IV & 13 & 14.7 \\
\hline CN VI & 30 & 8.9 \\
\hline Reduction in visual field (\%) & 64 & 33.3 \\
\hline Reduction of visual acuity (\%) & 52 & 43.7 \\
\hline Altered consciousness (\%) & 8 & 15 \\
\hline \multicolumn{3}{|l|}{ Radiological findings } \\
\hline CT scan (\%) & 94.6 & 79.3 \\
\hline Pituitary tumor (\%) & 94 & 91.3 \\
\hline Pituitary hemorrhage (\%) & 46 & 42 \\
\hline \multicolumn{3}{|l|}{ Management } \\
\hline No surgery (\%) & 2.7 & 29.9 \\
\hline $\begin{array}{l}\text { Interval between onset \& surgery } \\
\text { (days) }\end{array}$ & 16.8 & 6.8 \\
\hline \multicolumn{3}{|l|}{ Adenoma type } \\
\hline Null cell (\%) & 52 & 29.5 \\
\hline Prolactinoma (\%) & 17 & 13.2 \\
\hline Gonadotrophic (\%) & 13 & 1.6 \\
\hline Corticotrophic (\%) & 9 & 9.8 \\
\hline \multicolumn{3}{|l|}{ Postoperative visual outcomes } \\
\hline Visual acuity improvement (\%) & 88 & 94.4 \\
\hline Visual field deficits (\%) & 95 & 93.3 \\
\hline Ocular paresis (\%) & 100 & 100 \\
\hline \multicolumn{3}{|l|}{ Hormone deficiency } \\
\hline Hypoadrenalism (\%) & 82 & 60 \\
\hline Hypothyroidism (\%) & 89 & 62.7 \\
\hline Hypotestosteronism (\%) & 64 & 63.6 \\
\hline Diabetes insipidus (\%) & 11 & 10 \\
\hline
\end{tabular}

without severe neuro-ophthalmological deficits and for those who respond quickly to early medical therapy

We compared our current results (for the period between 1992 and 2013) with our previous experience between 1975 and $1991^{8}$ (Table 6). The main difference is a greater number of patients treated conservatively in the more recent past. As previously mentioned, the lower rates of ophthalmoparesis and visual field deficits in the current series can be explained by earlier diagnosis enabled by MRI. Outcomes were generally excellent in both series. Yet, there has been a small decline in the rates of longterm hypoadrenalism and hypothyroidism.
The main strengths of our study are the relatively large size of our cohort and the detailed and prolonged followup. However, it also has limitations. Treatment selection bias affects the comparison between conservative and surgical therapy groups, a limitation that our study shares with all previous ones, as no randomized studies of medical versus surgical treatment of pituitary apoplexy have ever been conducted. Also, not all patients had neurological, endocrinological, and ophthalmological evaluations at every time point of follow-up. Lastly, it is possible that we may have missed very mild cases of pituitary apoplexy that were treated in the ambulatory setting and were not called apoplexy by their treating physician.

\section{Conclusions}

We conclude that pituitary apoplexy is an eminently treatable condition that is generally characterized by a very favorable outcome when adequate treatment is provided in a timely manner. Selected cases can be managed conservatively, but surgery is associated with excellent outcomes and a very low risk of complications in experienced hands. Patients with pituitary apoplexy may need long-term hormone replacement, but they can be informed that the prognosis is otherwise excellent in the vast majority of cases, even among those presenting with neuroophthalmological deficits.

\section{References}

1. Abbott J, Kirkby GR: Acute visual loss and pituitary apoplexy after surgery. BMJ 329:218-219, 2004

2. Alzetani A, Fisher C, Costa R, Ohri SK: Ptosis postcardiac surgery: a case of pituitary apoplexy. Ann Thorac Surg 73:300-301, 2002

3. Arafah BM, Harrington JF, Madhoun ZT, Selman WR: Improvement of pituitary function after surgical decompression for pituitary tumor apoplexy. J Clin Endocrinol Metab 71:323-328, 1990

4. Arafah BM, Taylor HC, Salazar R, Saadi H, Selman WR: Apoplexy of a pituitary adenoma after dynamic testing with gonadotropin-releasing hormone. Am J Med 87:103-105, 1989

5. Ayuk J, McGregor EJ, Mitchell RD, Gittoes NJ: Acute management of pituitary apoplexy-surgery or conservative management? Clin Endocrinol (Oxf) 61:747-752, 2004

6. Bailey P: Pathological report of a case of acromegaly with especial reference to the lesion in the hypophysis cerebri and in the thyroid gland; and a case of hemorrhage into the pituitary. Philadelphia Med J 1:789-792, 1898

7. Bamfo JE, Sharif S, Donnelly T, Cohen MA, Golara M: A case of pituitary apoplexy masquerading as hyperemesis gravidarum. J Obstet Gynaecol 31:662, 2011

8. Bills DC, Meyer FB, Laws ER Jr, Davis DH, Ebersold MJ, Scheithauer BW, et al: A retrospective analysis of pituitary apoplexy. Neurosurgery 33:602-609, 1993

9. Biousse V, Newman NJ, Oyesiku NM: Precipitating factors in pituitary apoplexy. J Neurol Neurosurg Psychiatry 71:542-545, 2001

10. Bonicki W, Kasperlik-Załuska A, Koszewski W, Zgliczyński W, Wisławski J: Pituitary apoplexy: endocrine, surgical and oncological emergency. Incidence, clinical course and treatment with reference to 799 cases of pituitary adenomas. Acta Neurochir (Wien) 120:118-122, 1993

11. Brougham M, Heusner AP, Adams RD: Acute degenerative changes in adenomas of the pituitary body-with special reference to pituitary apoplexy. J Neurosurg 7:421-439, 1950 
12. Cardoso ER, Peterson EW: Pituitary apoplexy: a review. Neurosurgery 14:363-373, 1984

13. da Motta LA, de Mello PA, de Lacerda CM, Neto AP, da Motta LD, Filho MF: Pituitary apoplexy. Clinical course, endocrine evaluations and treatment analysis. J Neurosurg Sci 43:25-36, 1999

14. de Heide LJ, van Tol KM, Doorenbos B: Pituitary apoplexy presenting during pregnancy. Neth J Med 62:393-396, 2004

15. De la Torre M, Alcázar R, Aguirre M, Ferreras I: The dialysis patient with headache and sudden hypotension: consider pituitary apoplexy. Nephrol Dial Transplant 13:787-788, 1998

16. Dubuisson AS, Beckers A, Stevenaert A: Classical pituitary tumour apoplexy: clinical features, management and outcomes in a series of 24 patients. Clin Neurol Neurosurg 109:63-70, 2007

17. Gruber A, Clayton J, Kumar S, Robertson I, Howlett TA, Mansell P: Pituitary apoplexy: retrospective review of 30 patients - is surgical intervention always necessary? $\mathbf{B r} \mathbf{J}$ Neurosurg 20:379-385, 2006

18. Holness RO, Ogundimu FA, Langille RA: Pituitary apoplexy following closed head trauma. Case report. J Neurosurg 59:677-679, 1983

19. Knoepfelmacher M, Gomes MC, Melo ME, Mendonca BB: Pituitary apoplexy during therapy with cabergoline in an adolescent male with prolactin-secreting macroadenoma. Pituitary 7:83-87, 2004

20. Lazaro CM, Guo WY, Sami M, Hindmarsh T, Ericson K, Hulting AL, et al: Haemorrhagic pituitary tumours. Neuroradiology 36:111-114, 1994

21. Lee DH, Chung MY, Chung DJ, Kim JM, Lee TH, Nam JH, et al: Apoplexy of pituitary macroadenoma after combined test of anterior pituitary function. Endocr J 47:329-333, 2000

22. Levy A: Hazards of dynamic testing of pituitary function. Clin Endocrinol (Oxf) 58:543-544, 2003

23. Leyer C, Castinetti F, Morange I, Gueydan M, Oliver C, Conte-Devolx B, et al: A conservative management is preferable in milder forms of pituitary tumor apoplexy. J Endocrinol Invest 34:502-509, 2011

24. Lubina A, Olchovsky D, Berezin M, Ram Z, Hadani M, Shimon I: Management of pituitary apoplexy: clinical experience with 40 patients. Acta Neurochir (Wien) 147:151-157, 2005

25. Maccagnan P, Macedo CL, Kayath MJ, Nogueira RG, Abucham J: Conservative management of pituitary apoplexy: a prospective study. J Clin Endocrinol Metab 80:2190-2197, 1995

26. Mohr G, Hardy J: Hemorrhage, necrosis, and apoplexy in pituitary adenomas. Surg Neurol 18:181-189, 1982

27. Nagarajan DV, Bird D, Papouchado M: Pituitary apoplexy following anticoagulation for acute coronary syndrome. Heart 89:10, 2003

28. Nawar RN, AbdelMannan D, Selman WR, Arafah BM: Pituitary tumor apoplexy: a review. J Intensive Care Med 23:75-90, 2008

29. Onesti ST, Wisniewski T, Post KD: Clinical versus subclinical pituitary apoplexy: presentation, surgical management, and outcome in 21 patients. Neurosurgery 26:980-986, 1990

30. Rajasekaran S, Vanderpump M, Baldeweg S, Drake W, Reddy N, Lanyon M, et al: UK guidelines for the management of pituitary apoplexy. Clin Endocrinol (Oxf) 74:9-20, 2011

31. Randeva HS, Schoebel J, Byrne J, Esiri M, Adams CB, Wass JA: Classical pituitary apoplexy: clinical features, management and outcome. Clin Endocrinol (Oxf) 51:181-188, 1999

32. Schrupp Berg HL, Edlow JA: Post-partum pituitary apoplexy: a case report. Intern Emerg Med 2:311-314, 2007

33. Semple PL, De Villiers JC, Bowen RM, Lopes MB, Laws ER Jr: Pituitary apoplexy: do histological features influence the clinical presentation and outcome? J Neurosurg 104:931937, 2006

34. Verrees M, Arafah BM, Selman WR: Pituitary tumor apoplexy: characteristics, treatment, and outcomes. Neurosurg Focus 16(4):E6, 2004

35. Wakai S, Fukushima T, Teramoto A, Sano K: Pituitary apoplexy: its incidence and clinical significance. J Neurosurg 55:187-193, 1981

36. Weisberg LA: Pituitary apoplexy. Association of degenerative change in pituitary ademona with radiotherapy and detection by cerebral computed tomography. Am J Med 63:109-115, 1977

37. Willamowicz AS, Houlden RL: Pituitary apoplexy after anticoagulation for unstable angina. Endocr Pract 5:273-276, 1999

\section{Author Contributions}

Conception and design: Rabinstein, Singh, Valizadeh. Acquisition of data: Rabinstein, Singh, Valizadeh. Analysis and interpretation of data: Rabinstein, Singh. Drafting the article: Rabinstein, Singh. Critically revising the article: Rabinstein, Singh, Meyer, Atkinson, Erickson. Reviewed submitted version of manuscript: Rabinstein, Singh, Meyer. Approved the final version of the manuscript on behalf of all authors: Rabinstein. Statistical analysis: Singh. Study supervision: Rabinstein.

\section{Correspondence}

Alejandro A. Rabinstein, Department of Neurology, Mayo Clinic, 200 First St. SW, Mayo W8B, Rochester, MN 55905. email: rabinstein.alejandro@mayo.edu. 